\title{
RTN1 wt Allele
}

National Cancer Institute

\section{Source}

National Cancer Institute. RTN1 wt Allele. NCI Thesaurus. Code C54436.

Human RTN1 wild-type allele is located in the vicinity of $14 \mathrm{q} 23.1$ and is approximately $275 \mathrm{~kb}$ in length. This allele, which encodes reticulon-1 protein, is involved in the mediation of either neuroendocrine hormone secretion or membrane trafficking in neuroendocrine cells. 